\title{
Pengaruh Model Pembelajaran Probing Prompting Berbantuan Index Card Match Terhadap Prestasi Belajar Matematika Siswa Kelas X SMA Negeri 1 Sukasada
}

\author{
D. A. O. Setiawati ${ }^{1}$, I. G. P. Sudiarta ${ }^{2}$, I. M. Ardana ${ }^{3}$ \\ Program Studi S1 Pendidikan Matematika, Jurusan Matematika, Universitas Pendidikan Ganesha Singaraja, \\ Indonesia \\ e-mail:ayue.oka@gmail.com,gussudiarta@yahoo.de, ardanaimade@undiksha.ac.id
}

\begin{abstract}
Abstrak
Penelitian ini bertujuan untuk mengetahui apakah prestasi belajar matematika siswa kelas X SMA Negeri 1 Sukasada yang mengikuti pembelajaran matematika dengan model pembelajaran probing prompting berbantuan index card match lebih baik daripada prestasi belajar matematika siswa kelas X SMA Negeri 1 Sukasada yang mengikuti pembelajaran dengan model pembelajaran konvensional. Populasi dalam penelitian ini adalah siswa kelas X SMA Negeri 1 Sukasada tahun ajaran 2017/2018 yang berjumlah 202 orang siswa yang tersebar ke dalam 7 kelas. Pengambilan sampel dilakukan dengan teknik cluster random sampling untuk memperoleh 50 orang siswa yang tersebar ke dalam 2 kelas sebagai sampel penelitian. Sampel pada penelitian ini adalah siswa kelas X MIA 1 sebagai kelas kontrol dan siswa kelas X MIA 3 sebagai kelas eksperimen. Desain penelitian yang digunakan adalah Post Test Only Control Group Design. Data prestasi belajar matematika siswa diperoleh melalui tes prestasi belajar matematika. Analisis data dilakukan dengan menggunakan uji $t$ satu ekor dengan taraf signifikan $5 \%$, karena data prestasi belajar matematika siswa berdistirbusi normal dan homogen. Uji-t yang telah dilakukan memberikan hasil yaitu $t_{\text {hitung }}=6,8713$ dan nilai $t_{\text {tabel }}=0,063$. Karena nilai mutlak $\left|t_{\text {hitung }}\right|>t_{\text {tabel }}$, maka pada taraf signifikan $5 \%$, Ho ditolak. Artinya pada taraf signifikan $5 \%$, prestasi belajar matematika siswa kelas X SMA Negeri 1 Sukasada yang mengikuti pembelajaran matematika dengan model pembelajaran probing prompting berbantuan index card match lebih baik daripada prestasi belajar matematika siswa kelas X SMA Negeri 1 Sukasada yang mengikuti pembelajaran matematika dengan model pembelajaran konvensional.
\end{abstract}

Kata kunci: Probing Prompting, Index Card Match, Prestasi Belajar

\begin{abstract}
The study was aimed at finding out whether the achievement of the mathematics learning of tenth grade students of SMA Negeri 1 Sukasada who learn mathematics following probing prompting learning model that is assisted by index card match better than the achievement of mathematics learning of the tenth grade students of SMA Negeri 1 Sukasada who learn mathematics following the conventional learning. The population of this study was the thenth grade students of SMA Negeri 1 Sukasada on academic year 2017/2018 consisted of 202 students that is distributed into 7 classes. This research was using cluster random sampling technique to get the sample and the result was the 50 students that is spread into 2 classes as the subject of this research. The sample in this research were the students of class namely X MIA 1 as the control class and the students of class namely MIA 3 as the experimental class. This research was using Post Test Only Control Group Design. The data of the mathematics learning achievements were obtained through mathematics learning achievement test. The data were analyzed by using one tailed t-test that is using significance level of $5 \%$, because of the data of the students' mathematics learning achievements were normally and homogenously distributed. The result of the $t$-test is the $t_{\text {score }}=6,8713$ and the $t_{\text {table }} 0,063$. Because of $\left|t_{\text {hitung }}\right|>t_{\text {tabel, }}$, then $H_{0}$ is rejected. This means that at a significance level of $5 \%$, the achievement of the mathematics learning of tenth grade students of SMA Negeri 1 Sukasada who learn
\end{abstract}


mathematics following probing prompting learning model that is assisted by index card match better than the achievement of mathematics learning of the tenth grade students of SMA Negeri 1 Sukasada who learn mathematics following the conventional learning.

Keywords: Probing Prompting, Index Card Match, Learning Achievement.

\section{Pendahuluan}

Matematika merupakan salah satu disiplin ilmu yang mempunyai peranan penting di berbagai bidang, baik di bidang keilmuan maupun di bidang terapan. Banyak ilmu yang tidak dapat berkembang tanpa didasari oleh matematika seperti halnya ilmu fisika, kimia, biologi, ekonomi, astronomi dan lain sebagainya. Selain itu matematika juga dikatakan sebagai ilmu universal, dimana matematika juga mendasari perkembangan teknologi modern seperti teknologi kedokteran, pertanian, informasi dan lain sebagainya. Dengan kata lain teknologi yang merupakan bagian dari ilmu pengetahuan juga sangat bergantung pada matematika. Selain itu, disadari atau tidak aktivitas atau kegiatan yang dilakukan dalam kehidupan sehari-hari berkaitan dengan matematika seperti menghitung uang saat berbelanja, menghitung waktu, dan lain sebaginya. Sudiarta (2007) menyatakan bahwa pentingnya matematika dalam pasar dunia, dimana akan ada peningkatan kebutuhan untuk pekerja yang memiliki skill teknis dan matematis yang maju dan berorientasi masa depan. Oleh karena itu matematika sangat diperlukan dalam kehidupan sehari-hari maupun kemajuan ilmu pengetahuan dan teknologi.

Menurut Syah (2008) prestasi belajar adalah taraf keberhasilan siswa dalam mempelajari materi pelajaran di sekolah yang dinyatakan dalam bentuk skor yang diperoleh dari hasil tes mengenai sejumlah materi pelajaran tertentu. Prestasi belajar matematika adalah hasil yang telah dicapai atau diperoleh siswa berupa skor dalam mata pelajaran matematika (Suryantini, 2016) Prestasi belajar matematika siswa di Indonesia masih tergolong rendah. Hal ini dapat dilihat dari beberapa hasil survey internasional seperti Trends in International Mathematics and Science Study (TIMSS) dan Program for International Student Assesment (PISA). TIMSS adalah salah satu studi banding yang bertujuan untuk mengukur sikap dan kemampuan siswa kelas 4 dan kelas 8 dalam bidang sains dan matematika yang diselenggarakan setiap 4 tahun sekali. Hasil survey TIMSS pada tahun 2015 menunjukan bahwa Indonesia memperoleh peringkat 44 dari 49 negara (TIMSS, 2015). PISA merupakan survey tentang kemampuan siswa dan sistem pendidikan yang diselenggarakan setiap 3 tahun sekali. Hasil studi PISA pada tahun 2015 menunjukan bahwa dalam bidang matematika, Indonesia memperoleh peringkat 63 dari 70 negara (OECD, 2016).

Rendahnya prestasi belajar matematika siswa disebabkan oleh dua faktor yaitu faktor internal dan faktor eksternal. Salah satu faktor internal yang menyebabkan rendahnya prestasi belajar matematika yaitu minat belajar siswa terhadap matematika dirasa masih begitu rendah. Minat belajar dapat diartikan sebagai rasa senang atau keinginan yang besar atau ketertarikan peserta didik untuk menguasai pengetahuan dan pengalaman tanpa ada paksaan, hal tersebut dapat ditunjukan melalui partisipasi dan keaktifan dalam mencari pengetahuan dan pengalaman (Retno, 2016). Terdapat empat indikator minat belajar yaitu perasaan senang, ketertarikan untuk belajar, menunjukan perhatian saat belajar, dan keterlibatan dalam belajar (Lestari dan M. Ridwan, 2015).

Menurut Sukendra (2014) banyak kalangan menyatakan bahwa minat siswa untuk belajar matematika masih rendah, karena sebagian besar siswa masih menganggap matematika sebagai mata pelajaran yang menakutkan dan membosankan. Hal ini akan mempengaruhi prestasi belajar siswa. Pernyataan ini sejalan dengan hasil penelitian yang dilakukan oleh Lisa Kamranti Retno pada tahun 2016 yang berjudul Pengaruh Minat Belajar pada Pembelajaran Matematika terhadap Prestasi Belajar Peserta Didik Mata Pelajaran Matematika Kelas IV MI Sultan Fatah Demak Tahun Ajaran 2015/2016. Penelitian ini menyimpulkan bahwa minat belajar matematika berpengaruh positif terhadap prestasi belajar peserta didik mata pelajaran matematika kelas IV MI Sultah Fatah Demak. 
Selain itu, permasalahan yang dialami siswa tidak hanya bersumber pada kemampuan siswa yang kurang serta minatnya yang rendah, tetapi ada faktor lain yang ikut menentukan keberhasilan siswa dalam belajar matematika, salah satu diantaranya adalah model pembelajaran yang dipilih oleh guru sebagai pengajar. Berdasarkan permasalahan tersebut perlu diadakannya perubahan dalam pelaksanaan pembelajaran matematika agar tidak menoton yang mampu meningkatkan prestasi belajar matematika siswa. Salah satu alternatif yang dapat digunakan untuk membantu guru dalam pembelajaran matematika yaitu dengan memilih model pembelajaran yang tepat dan inovatif. Model pembelajaran merupakan kerangka konseptual yang menggambarkan prosedur sistimatis dalam mengorganisasikan pengalaman belajar untuk mencapai tujuan tertentu serta berfungsi sebagai pedoman dalam merencanakan dan melaksanakan pembelajaran (Sudiarta, 2010). Terdapat banyak model pembelajaran yang dapat digunakan untuk meningkatkan prestasi belajar siswa salah satunya adalah model pembelajaran probing prompting.

Menurut Suherman (dalam Lestari dan M. Ridwan, 2015:66) model pembelajaran probing prompting adalah suatu model pembelajaran dimana guru menyajikan serangkaian pertanyaan yang sifatnya menuntun dan menggali sehingga terjadi proses berpikir yang mengaitkan pengetahuan setiap siswa dan pengalamannya dengan pengetahuan baru yang sedang dipelajari. Dalam model pembelajaran probing prompting terdapat dua jenis pertanyaan yaitu probing question atau pertanyaan yang bersifat menggali dan prompting question atau pertanyaan yang bersifat mendorong. Menurut Suherman (dalam Huda, 2014:281) Probing question adalah pertanyaan yang bersifat menggali untuk mendapatkan jawaban lebih dalam dari siswa yang bermaksud mengembangkan kualitas jawaban, sehingga jawaban berikutnya lebih jelas, akurat serta beralasan.

Contoh :

Guru : Jika diberikan suatu pernyataan $\frac{1}{6}$ putaran $=0,333 \pi$ rad . Apakah pernyataan tersebut bernilai benar atau salah?

Siswa: Benar bu.

Guru : Coba berikan alasan mengapa pernyataan tersebut dikatakan benar?

Sedangkan prompting question merupakan pertanyaan yang diajukan untuk memberi arahan kepada siswa dalam proses berpikirnya agar siswa dapat menemukan jawaban yang lebih benar. Prompting question ini merupakan cara lain untuk merespon atau menanggapi jawaban siswa ketika jawaban yang diberikan siswa kurang tepat atau salah. Oleh karena itu ada tiga tipe pertanyaan yang merupakan prompting question yaitu (1) menyusun ulang pertanyaan dengan kata-kata yang lebih sederhana; (2) memberikan pertanyaan-pertanyaan lain yang mengarahkan siswa untuk mendapatkan jawaban dari pertanyaan semula; (3) meminta siswa untuk mengulang kembali (review) penyelesaian masalah yang sudah diperoleh untuk menguatkan pengetahuan siswa.

Contoh:

Guru: Jika diberikan suatu pernyataan $\frac{1}{6}$ putaran $=0,333 \pi$ rad. Apakah pernyataan tersebut

bernilai benar atau salah?

Siswa : menunjukan ekspresi berpikir.

Guru : $\frac{1}{6}$ putaran itu berapa derajat? Bagaimana hubungan derajat dengan radian?

Dalam model pembelajaran probing prompting, proses tanya jawab dilakukan dengan menunjuk siswa secara acak sehingga setiap siswa mau tidak mau harus berpartisipassi aktif, sehingga setiap saat siswa bisa dilibatkan dalam proses tanya jawab (Huda, 2014).

Salah satu masalah yang sering dialami dalam pelaksanaan pembelajaran matematika adalah kurangnya kesiapan siswa menerima pelajaran. Masalah ini dapat menghambat pembelajaran yang dilaksanakan. Untuk mengatasi masalah tersebut, model pembelajaran yang digunakan dalam pembelajaran di kelas dapat dikombinasikan dengan menggunakan media atau 
permainan yang menarik dan menyenangkan tetapi tidak lepas dari materi yang diajarkan. Dalam penelitian ini, peneliti menduga bahwa dengan menggunakan suatu permainan index card match dapat meningkatkan minat belajar siswa dalam proses pembelajaran di kelas. Permainan ini juga merupakan salah satu cara yang menyenangkan untuk meninjau ulang materi sebelumnya, namun materi baru juga tetap bisa diajarkan. Cara bermain permainan index card match ini adalah dengan mencari pasangan kartu yang sesuai. Dimana siswa akan dibagikan sebuah kartu, sebagian dibagikan kartu yang berisi soal dan sebagiannya lagi dibagikan kartu yang berisi jawaban. Tugas siswa adalah mencari pasangan kartu dari kartu yang dibawanya. Contoh :

\begin{tabular}{|c|c|}
\hline KARTU SOAL 01 & KARTU JAWABAN 01 \\
\hline $\begin{array}{l}\text { Suatu jam dinding } \\
\text { sedang menunjukan } \\
\text { pukul } 12.05 \text {. } \\
\text { Berapakah besar } \\
\text { sudut yang dibentuk } \\
\text { oleh jarum jam } \\
\text { tersebut } \\
\text { radian? dalam }\end{array}$ & $\frac{1}{6} \pi \mathrm{rad}$ \\
\hline
\end{tabular}

Model pembelajaran probing prompting berbantuan index card match adalah model pembelajaran probing prompting dengan memanfaatkan permainan kartu sebagai bantuan dalam menghadapkan siswa pada situasi baru, dimana pada kartu tersebut berisikan suatu permasalahan. Pembelajaran dikelas berlangsung sesuai dengan langkah-langkah kegiatan model pembelajaran probing promting yang dikombinasikan dengan permainan index card match.

Sesuai dengan tujuan digunakannya permainan ini yaitu sebagai bantuan dalam menghadapkan siswa pada situasi baru, maka permainan ini disisipkan pada tahap awal model pembelajaran probing prompting. Selanjutnya siswa diberikan waktu untuk menyelesaikan permasalahan yang ada pada kartu dan mencari pasangannya. Setelah siswa menemukan pasangannya, salah satu siswa yang mendapat kartu soal akan membacakan soal tersebut agar siswa lain dapat mencoba menyelesaikan masalah yang dibacakan. Lalu pasangan dari siswa tersebut menjelaskan penyelesaian dari permasalahan yang ada. Jika jawaban siswa tersebut benar, siswa yang lain dapat memberikan tanggapan untuk meyakinkan jawaban, bahwa semua siswa terlibat dalam kegiatan pembelajaran. Namun jika jawaban siswa tersebut kurang tepat atau tidak tepat maka guru akan mengajukan pertanyaan lain jawabannya merupakan petunjuk jalan penyelesaian jawaban. Kemudian dilanjutkan dengan pertanyaan yang menuntut siswa berpikir pada tingkat yang lebih tinggi, sampai siswa dapat menjawab pertanyaan sesuai dengan kompetensi dasar atau indikator. Pada tahap akhir akan diberikan suatu pertanyaan akhir kepada siswa yang berbeda untuk lebih memastikan bahwa indikator yang dicapai telah dipahami oleh siswa. Proses pembelajaran ini lebih menarik diterapkan karena siswa mencari pasangan sambil belajar mengenai suatu topik dalam suasana yang menyenangkan, sehingga dengan menggunakan permainan ini dapat menciptakan pembelajaran yang aktif, kreatif, efektif, dan menyenangkan.

Beberapa hasil penelitian pun menunjukan bahwa model pembelajaran probing prompting dan index card match efektif digunakan dalam pembelajaran. Pertama, penelitian yang dilakukan penelitian yang dilakukan Purwadi (2016) menyatakan bahwa model pembelajaran probing prompting berpengaruh positif terhadap kemampuan pemahaman konsep matematika siswa pada materi bangun ruang sisi datar, namun penelitian ini hanya terbatas pada pengaruh model pembelajaran probing promting terhadap pemahaman konsep matematika siswa pada materi bangun ruang sisi datar. Kedua, penelitian yang dilakukan oleh juniari (2016) menyebutkan bahwa model pembelajaran probing prompting berpengaruh terhadap kesiapan belajar matematika dan kemampuan berpikir kritis matematika siswa, namun penelitian ini hanya terbatas pada pengaruh model pembelajaran probing promting terhadap kesiapan belajar 
matematika dan kemampuan berpikir kritis matematika siswa. Selain itu penelitian ini juga terbatas pada pokok bahasan bangun ruang sisi datar. Ketiga, penelitian yang dilakukan oleh Dewi (2017) menyimpulkan bahwa terdapat pengaruh model pembelajaran probing prompting terhadap hasil belajar matematika siswa, namun penelitian ini dilakukan pada tingkat SMP kelas VIII. Keempat, yakni penelitian yang dilakukan oleh Nugraha (2013) menyatakan bahwa penggunaan metode pembelajaran think pair share (TPS) yang dilengkapi media index card match (ICM) efektif digunakan untuk menigkatkan prestasi belajar siswa kelas X SMA N 2 Karanganyar pada materi ikatan kimia, namun penelitian ini terbatas pada materi ikatan kimia. Kelima, penelitian yang dilakukan oleh Nurmawati (2015) menyimpulkan bahwa ada pengaruh penerapan metode index card match terhadap prestasi belajar matematika siswa, namun penelitian ini hanya terbatas pada materi volume kubus dan balok. Selain itu subyek penelitiannya sebanyak 2 orang yang merupakan siswa kelas V SLB-A YKAB Surakarta.

Berdasarkan paparan di atas, dapat disimpulkan bahwa pengaruh model pembelajaran probing prompting berbantuan index card match terhadap prestasi belajar matematika siswa sangat penting untuk diteliti, karena belum ada bukti empiris yang menunjukan bahwa model pembelajaran probing prompting dengan berbantuan index card match berpengaruh positif terhadap prestasi belajar matematika siswa.

Sehingga fokus penelitian ini adalah untuk menjawab pertanyaan; Apakah prestasi belajar matematika siswa kelas X SMA Negeri 1 Sukasada mengikuti pembelajaran matematika dengan model pembelajaran probing prompting berbantuan index card match lebih baik dari pada prestasi belajar matematika siswa kelas X SMA Negeri 1 Sukasada yang mengikuti pembelajaran matematika dengan model pembelajaran konvensional?

\section{Metode}

Jenis penelitian ini adalah penelitian eksperimen yang tergolong katagori penelitian eksperimen semu (quasi eksperimen). Karena pada penelitian ini peneliti hanya melihat pengaruh yang timbul setelah diberikan perlakuan yang berbeda terhadap masing-masing kelompok.

Populasi dalam penelitian ini adalah siswa kelas X SMA Negeri 1 Sukasada tahun ajaran 2017/2018. Banyak populasi dalam penelitian ini adalah 202 orang siswa yang tersebar ke dalam 7 kelas. Pengambilan sampel dalam penelitian ini dilakukan dengan teknik cluster random sampling, dimana cluster random sampling ini merupakan teknik pemilihan atau pengambilan sampel berdasarkan pada suatu kelompok bukan berdasarkan individual. Penentuan sampel dengan menggunakan teknik cluster random sampling dikarenakan sampel dalam penelitian ini adalah kelompok siswa dalam bentuk kelas-kelas yang sudah ada, dan tidak dimungkinkan membentuk kelas-kelas baru dengan cara mengacak individu anggota populasi. Dengan menggunakan teknik cluster random sampling dipilih dua kelas. Kelas yang terambil adalah kelas X MIA 1 dan X MIA 3, kemudian kedua kelas tersebut akan diuji kesetaraannya. Penyetaraan ini dilakukan untuk menjamin bahwa hasil post test yang diperoleh semata mata disebabkan oleh perlakuan (treatment) yang diberikan pada penelitian ini. Uji kesetaraan ini dilakukan dengan menggunakan uji- $t$ dua ekor untuk dua sampel bebas dengan menggunakan taraf signifikan $5 \%$. Data yang digunakan adalah data nilai UAS semester ganjil kelas X SMA Negeri 1 Sukasada tahun pelajaran 2017/2018. Sebelum dilakukan uji kesetaraan, diperiksa dahulu normalitas dan homogenitas data yang akan diuji. Adapun uji normalitas menggunakan uji Lilliefors dan uji homogenitas dengan uji Levene

Setelah dilakukan uji kesetaraan terhadap kedua kelompok sampel dan diperoleh hasil bahwa kedua kelompok setara, kemudian secara acak dipilih satu kelompok sebagai kelompok kontrol dan satu kelompok sebagai kelompok eksperimen. Dari hasil pengundian antara kedua kelompok, diperoleh kelas X MIA 3 sebagai kelompok eksperimen dan kelas X MIA 1 sebagai kelompok kontrol. Kelompok kontrol adalah kelompok yang menerapkan pembelajaran 
matematika konvensional sedangkan kelompok eksperimen adalah kelompok yang menerapkan model pembelajaran probing prompting berbantuan index card match dalam pembelajarannya.

Penelitian ini melibatkan variabel bebas dan varibel terikat. Variabel bebas dalam penelitian ini adalah model pembelajaran, dengan variasi model probing prompting berbantuan index card match dan model pembelajaran konvensional yang digunakan dalam pembelajaran matematika di SMA Negeri 1 Sukasada. Sedangkan Variabel terikat dalam penelitian ini adalah prestasi belajar matematika siswa. Rancangan penelitian yang digunakan dalam penelitian ini adalah post test only control group design

Instrumen yang digunakan dalam mengumpulkan data pada penelitian ini adalah tes prestasi belajar matematika yang berbentuk tes uraian. Dimana data yang digunakan berupa skor dari hasil tes prestasi belajar matematika siswa. Bentuk tes uraian digunakan untuk meminimalkan faktor untung-untungan dan kerjasama pada hasil tes siswa. Data pada penelitian ini adalah skor prestasi belajar matematika siswa yang dikumpulkan melalui tes berbentuk uraian.

Instrumen yang digunakan haruslah instrumen yang valid dan reliabel agar mendapatkan hasil penelitian yang valid dan reliabel. Dengan demikian sebelum instrumen digunakan, instrumen harus diujicobakan terlebih dahulu untuk mengetahui validitas dan reliabilitasnya. Uji validitas isi instrumen dilakukan oleh dua orang pakar untuk menguji apakah tes yang dibuat relevan atau tidak. Kemudian dilakukan uji coba dan hasil uji coba tersebut digunakan untuk menguji validitas tes dan reliabilitas. Untuk mengukur validitas tes digunakan rumus korelasi product-moment Carl Pearson (Candiasa, 2010) sebagai berikut.

$$
r_{x y}=\frac{n \sum X Y-\left(\sum X\right)\left(\sum Y\right)}{\sqrt{\left(n \sum X^{2}-\left(\sum X\right)^{2}\right)\left(n \sum Y^{2}-\left(\sum Y\right)^{2}\right)}}
$$

Setelah menguji validitas, dilanjutkan dengan pengujian reliabilitas. Untuk menguji reliabilitas digunakan rumus alpha cronbach (Candiasa, 2010) sebagai berikut.

$$
r_{11}=\left(\frac{n}{n-1}\right)\left(1-\frac{\sum \sigma_{i}^{2}}{\sum \sigma_{t}^{2}}\right)
$$

Berdasarkan uji coba yang telah dilakukan diperoleh hasil bahwa 7 butir soal dari 9 butir yang diujicobakan adalah soal yang valid dan memiliki derajat reliabilitas yang tinggi dengan nilai $r_{11}$ sebesar 0,6691. Sehingga soal tersebut layak digunakan dalam penelitian ini.

Setelah mengadakan posttest dan mendapatkan data berupa skor, maka selanjutnya data tersebut digunakan untuk melakukan uji hipotesis. Sebelum melaukan uji hipotesis, terlebih dahulu dilakukan uji prasyarat yaitu uji normalitas dan uji homogenitas varians. Untuk uji normalitas digunakan Uji Lilliefors, sedangkan uji homogenitas varians menggunakan Uji Levene. Jika data berdistribusi normal dan homogen maka untuk menguji hipotesisnya digunakan uji- $t$ satu ekor dengan taraf signifikan $5 \%$. Rumus uji-t yang digunakan, yaitu sebagai berikut. (Candiasa, 2010b:58)

dengan

$$
t=\frac{\overline{Y_{1}}-\overline{Y_{2}}}{s \sqrt{\frac{1}{n_{1}}+\frac{1}{n_{2}}}}
$$

$$
\begin{aligned}
& \qquad s^{2}=\frac{\left(n_{1}-1\right) s_{1}^{2}+\left(n_{2}-1\right) s_{2}^{2}}{\left(n_{1}+n_{2}-2\right)} \\
& \text { Kriteria pengujian adalah terima } H_{0} \text { jika }\left|t_{\text {hitung }}\right|<t_{\text {tabel }} \text { dimana } t_{\text {tabel }}=t_{(1-\alpha)(d k)} \text { dengan }
\end{aligned}
$$
derajat kebebasan $d k=\left(n_{1}+n_{2}-2\right)$ dan $\alpha=5 \%$ 


\section{Hasil dan Pembahasan}

Rangkuman analisis data prestasi belajar siswa pada kelompok kontrol dan kelompok eksperimendapatdilihatpadaTabel1

Tabel 1. Rangkuman Analisis Data Prestasi Belajar Siswa

\begin{tabular}{cccc}
\hline \multirow{2}{*}{ No. } & Variabel & \multicolumn{3}{c}{ Kelompok } \\
\cline { 3 - 4 } & $\mathrm{N}$ & Kontrol & Eksperimen \\
\hline 1. & $\bar{Y}$ & 24 & 26 \\
\hline 2. & $\mathrm{SD}$ & 49,1667 & 108,2692 \\
\hline 3. & 27,9933 & 32,4315 \\
\hline
\end{tabular}

Berdasarkan Tabel 1 dapat dilihat bahwa rata-rata skor prestasi belajar matematika siswa pada kelompok eksperimen yang menerapkan model pembelajaran probing prompting berbantuan index card match dalam pembelajarannya lebih tinggi daripada rata-rata skor prestasi belajar matematika siswa pada kelompok kontrol yang menerapkan pembelajaran konvensional.

Sebelum uji hipotesis dilakukan, terlebih dahulu dilakukan pengujian prasyarat yaitu uji normalitas dan homogenitas varians terhadap data skor pemahaman konsep matematika siswa. Pengujian normalitas sebaran data prestasi belajar matematika siswa dilakukan dengan Uji Lilliefors pada taraf sig. 5\%. Rangkuman pengujian normalitas dapat dilihat pada Tabel 2.

Tabel 2. Rangkuman Hasil Uji Normalitas Skor Prestasi Belajar Siswa

\begin{tabular}{ccccc}
\hline No & Kelompok & L hitung & $\mathbf{L}_{\text {tabel }}$ & Keterangan \\
\hline 1 & Kontrol & 0,1700 & 0,1764 & Normal \\
\hline 2 & Eksperimen & 0,1046 & 0,1706 & Normal \\
\hline
\end{tabular}

Berdasarkan Tabel 2 dapat dilihat bahwa hasil uji normalitas data prestasi belajar matematika siswa pada kelas eksperimen diperoleh $L_{\text {hitung }}=0,1046<L_{\text {tabel }}=0,1706$ (untuk $\mathrm{N}=$ 26 pada taraf signifikansi $5 \%$ ) dan pada kelompok kontrol diperoleh $L_{\text {nitung }}=0,17<L_{\text {tabel }}=0,1764$ (untuk $n=24$ pada taraf signifikansi $5 \%$ ), maka $H_{0}$ diterima yang berarti kedua kelas sampel memiliki data yang berdistribusi normal.

Selanjutnya, hasil perhitungan homogenitas varians yang diuji dengan uji Levene. Rangkuman pengujian homogenitas tersebut dapat dilihat pada Tabel 3.

Tabel 3. Rangkuman Hasil Uji Homogenitas Varians Skor Prestasi Belajar Siswa

\begin{tabular}{|c|c|c|c|c|c|}
\hline No & Kelompok & Varians & $w$ & $F_{\text {tabel }}$ & Keterangan \\
\hline 1 & Kontrol & 783,6232 & \multirow{2}{*}{0,1692} & \multirow{2}{*}{4,0427} & \multirow{2}{*}{ Homogen } \\
\hline 2 & Eksperimen & 1051,8046 & & & \\
\hline
\end{tabular}

Berdasarkan Tabel 3 dapat dilihat bahwa nilai $W=0,1692$ dan nilai $F_{\text {tabel }}=4,0427$. Apabila nilai $W$ dibandingkan dengan nilai $F_{\text {tabel }}$ maka nilai $W<F_{\text {tabel. }}$. Dengan demikian $H_{0}$ diterima dan hal tersebut berarti tidak ada perbedaan varians antara kelompok eksperimen dan kelompok kontrol atau dengan kata lain varians kedua data homogen.

Berdasarkan hasil uji normalitas dan homogenitas varians diperoleh bahwa data prestasi belajar matematika siswa untuk kelas eksperimen dan kelas kontrol berdistristribusi normal dan memiliki varians yang homogen. Maka dari itu, pengujian hipotesis bisa dilakukan dengan menggunakan uji-t satu ekor. Rangkuman hasil pengujian data prestasi belajar matematika siswa dengan menggunakan uji- $t$ disajikan pada Tabel 4. 
Tabel 4. Rangkuman Hasil Analisis Uji-t terhadap Skor Prestasi Belajar Siswa

\begin{tabular}{|c|c|c|c|c|c|}
\hline Kelompok & Rata-Rata & $t_{\text {hitung }}$ & dk & $\mathbf{t}_{\text {tabel }}$ & Kesimpulan \\
\hline Kontrol & 49,1667 & \multirow{2}{*}{6,8713} & \multirow{2}{*}{48} & \multirow{2}{*}{0,063} & \multirow{2}{*}{ Tolak $\mathrm{H}_{0}$} \\
\hline Eksperimen & 108,2692 & & & & \\
\hline
\end{tabular}

Berdasarkan perhitungan pada Tabel.4, diperoleh $t_{\text {hitung }}=6,8713$ sedangkan $t_{\text {tabel }}$ untuk $\mathrm{dk}$ $=48$ dengan taraf signifikansi $5 \%$ adalah 0,063 . Karena $\left|t_{\text {hitung }}\right|>t_{\text {tabel }}$ maka dapat diambil kesimpulan $H_{0}$ ditolak. Artinya pada taraf signifikan $5 \%$, prestasi belajar matematika siswa kelas $X$ SMA Negeri 1 Sukasada yang mengikuti pembelajaran matematika dengan model pembelajaran probing prompting berbantuan index card match lebih baik daripada prestasi belajar matematika siswa kelas X SMA Negeri 1 Sukasada yang mengikuti pembelajaran matematika dengan model konvensional.

\section{Pembahasan}

Pengujian hipotesis penelitian ini memberikan hasil bahwa prestasi belajar matematika siswa kelas X SMA Negeri 1 Sukasada yang mengikuti pembelajaran matematika dengan model pembelajaran probing prompting berbantuan index card match lebih baik daripada prestasi belajar matematika siswa kelas X SMA Negeri 1 Sukasada yang mengikuti pembelajaran matematika dengan model pembelajaran konvensional.

Pembelajaran matematika yang menggunakan model pembelajaran probing prompting berbantuan index card match menjadikan siswa lebih terdorong untuk berpartisipasi aktif dalam proses pembelajaran, baik dalam mengerjakan masalah yang diberikan maupun menjawab pertanyaan yang dilontarkan oleh guru. Selama proses ini, siswa dituntut untuk bergerak aktif dalam mencari jawaban sekaligus mencari pasangan temannya. Hal ini tentu berbeda dengan pembelajaran konvensional yang dimana siswa hanya duduk di kelompoknya masing-masing. Dengan bantuan permainan index card match siswa terlihat lebih aktif dalam menggali informasi. Siswa merasa lebih senang dalam belajar dikarenakan pada fase ini, siswa dapat lebih fokus dalam belajar dan mengurangi rasa mengantuk. Siswa pada saat dibelajarkan dengan belajar kelompok biasa terkadang merasa mengantuk sehingga diskusi kelompok tidak berlangsung maksimal.

Sesuai dengan tujuan digunakannya permainan ini yaitu sebagai bantuan dalam menghadapkan siswa pada situasi baru, maka permainan ini disisipkan pada tahap awal model pembelajaran probing prompting. Selanjutnya siswa diberikan waktu untuk menyelesaikan permasalahan yang ada pada kartu dan mencari pasangannya. Kemudian guru menunjuk salah satu pasang siswa, siswa yang mendapat kartu soal akan membacakan soal terlebih dahulu agar siswa lain dapat mencoba menyelesaikan masalah yang dibacakan. Lalu pasangan dari siswa tersebut menjelaskan penyelesaian dari permasalahan yang ada. Jika jawaban yang sampaikan sesuai maka guru meminta tanggapan kepada siswa lain tentang jawaban tersebut dan memberikan penghargaan berupa nilai plus dan tepuk tangan. Tetapi jika jawaban yang disampaikan kurang tepat maka guru mengajukan pertanyaan-pertanyaan lain yang jawabannya merupakan pertanyaan pancingan untuk membangkitkan ingatan siswa dalam rangka mencari jawaban dari pertanyaan sebelumnya. Namun, sebelum guru memberikan pertanyaanpertanyaan pancingan guru menunjuk siswa lain terlebih dahulu untuk membantu menjawab. Apabila jawaban dirasa belum maksimal maka di sinilah peran pertanyaan prompting untuk diajukan oleh guru. Anonim (2011) menyebutkan pula bahwa, pengajuan prompting questions dilakukan jika pertanyaan yang diajukan dirasa "sulit" oleh siswa, sehingga guru perlu memberikan prompting questions dengan cara memberikan informasi tambahan yang sifatnya memancing agar siswa dapat menjawab atau mengubah pertanyaan dalam bentuk lain. Guru 
harus lebih terampil dalam memberikan atau mengajukan pertanyaan dengan jalan menguasai teknik-teknik bertanya dengan baik.

Pemberian pertanyaan pancingan tersebut juga dapat berfungsi sebagai review (meninjau kembali) pelajaran sebelumnya yang mengakibatkan siswa, menjadi lebih siap untuk mengikuti kegiatan pembelajaran. Di samping itu, dengan diberikannya pertanyaan-pertanyaan selama kegiatan pembelajaran, perhatian siswa menjadi lebih terpusat sehingga suasana belajar menjadi lebih kondusif. Jika jawaban sudah sesuai maka guru mengajukan pertanyaan akhir kepada siswa yang berbeda untuk lebih menekankan materi tersebut telah dipahami oleh seluruh siswa.

Proses pembelajaran ini lebih menarik diterapkan karena siswa mencari pasangan sambil belajar mengenai suatu topik dalam suasana yang menyenangkan, sehingga dengan menggunakan permainan ini dapat menciptakan pembelajaran yang aktif, kreatif, efektif, dan menyenangkan. Hal ini didukung dengan hasil penelitian yang dilakukan oleh Nugraha (2013) menyatakan bahwa penggunaan media kartu berpasangan (index card match) efektif digunakan untuk meningkatkan prestasi belajar. Selain itu pada proses mencari pasangan dalam permainan index card match dapat membuat siswa memiliki tanggung jawab individu disamping tanggung jawab kelompok. Hal ini dikarenakan setiap siswa mempunyai tugasnya masing-masing, dimana siswa yang mendapatkan kartu soal harus menyelesaikan soal yang ada pada kartu kemudian mencari temannya yang membawa kartu jawaban dari soal tersebut. Selanjutnya kedua siswa mendiskusikan soal tersebut untuk meyakinkan jawaban yang diperoleh siswa yang membawa kartu soal benar. Dan siswa yang membawa kartu jawaban bertugas untuk menjelaskan ke depan kelas ketika ditunjuk oleh guru. Tanggung jawab individu ini mencegah siswa berdiam diri saat pembelajaran berlangsung. Berdasarkan pengamatan peneliti, tanggung jawab individu siswa ini terlihat pada kesungguhan siswa saat mencari pasangan. Meraka selalu mendesak pasangannya dalam memberikan bantuan hingga mereka memahami penyelesaian dari permasalahan yang mereka tanyakan. Pada pembelajaran konvensional, biasanya terdapat celah dimana terdapat beberapa siswa yang hanya menumpang nilai pada anggota kelompok yang lainnya. Fase mencari pasangan ini dapat meminimalisir terjadinya hal tersebut.

Selain itu, proses tanya jawab dalam pembelajaran yang menerapkan model pembelajaran probing prompting berbantuan index card match dilakukan dengan menunjuk siswa secara acak sehingga setiap siswa mau tidak mau harus berpartisipasi aktif dan siswa tidak dapat menghindar dari proses pembelajaran, dengan kata lain siswa dapat dilibatkan dalam proses tanya jawab setiap saat. Hal ini akan memudahkan guru untuk melihat siswa yang sudah mampu memahami materi ataupun belum dari kualitas jawaban siswa. Di samping itu pada proses ini, jika siswa belum mampu menjawab dengan benar dan tepat, maka mereka akan dibantu oleh temannya untuk memberikan tanggapan. Begitupun jika siswa yang belum memahami lebih berani untuk menanyakan dan rasa canggung dalam bertanya bisa dikurangi.

Berbeda halnya dengan pembelajaran konvensional yang digunakan di kelas kontrol. Masih terdapat siswa yang bergantung dengan teman satu kelompoknya dalam menyelesaikan masalah kelompok. Hal yang terjadi adalah mereka menjadi tidak mengerti dengan apa yang telah dikerjakan teman satu kelompoknya. Dengan kata lain, rata-rata aktivitas siswa pada kelas kontrol cenderung lebih sedikit jika dibandingkan dengan kelas eksperimen.

Hasil Penelitian ini diperkuat dengan hasil penelitian yang dilakukan oleh Dewi (2017) dengan judul "Pengaruh Model Pembelajaran Probing Prompting Terhadap Hasil Belajar Matematika Siswa Kelas VIII SMP Negeri L Sidoharjo Tahun Pelajaran 2017/2018". Dari penelitian ini diperoleh kesimpulan bahwa terdapat pengaruh yang positif model pembelajaran probing prompting terhadap hasil belajar matematika siswa kelas VIII SMP Negeri L Sidoharjo.

Meskipun secara umum proses pembelajaran matematika dengan model pembelajaran probing prompting berbantuan index card match berjalan dengan baik, namun masih terdapat kendala dalam pelaksanaannya. Adapun kendala yang ditemui yaitu ketika siswa mencari pasangan dan berdiskusi dengan pasangannya memerlukan waktu yang relatif lama. Siswa terkadang kurang memanfaatkan waktu dengan efektif, sehingga proses ini berlangsung lebih 
lama dari yang seharusnya. Kendala ini dapat diatasi dengan memberikan batasan waktu untuk melakukan diskusi pasangan. Batasan waktu ini akan membuat waktu pembelajaran akan dapat dimanfaatkan dengan lebih efisien.

Meskipun memiliki kendala dalam pelaksanaannya, namun dengan menerapkan model pembelajaran probing prompting berbantuan index card match dalam pembelajaran matematika akan meningkatkan partisipasi dan aktivitas siswa dalam pembelajaran yaitu dengan menyelesaikkan setiap permasalahan yang diberikan baik secara individu maupun kelompok sehingga berdampak pada keberhasilan siswa dalam memahami materi pelajaran. Tentunya hal ini juga akan berdampak pada meningkatnya taraf keberhasilan siswa dalam mempelajari materi pelajaran di sekolah.

Ada beberapa hal yang perlu diperhatikan guru dalam menggunakan model pembelajaran probing prompting berbantuan index card match dalam pembelajaran matematika yaitu sebagai berikut.

a. Guru harus memperhatikan jenis permasalahan yang akan digunakan dalam pembelajaran. Jenis permasalahan yang terlalu sulit terutama dalam perhitungan akan menyebabkan waktu diskusi yang panjang, sehingga pembelajaran akan menjadi kurang efisien.

b. Guru harus memperhatikan soal-soal yang akan digunakan pada kartu agar siswa tidak mudah menebak jawaban. Jika soal yang mudah di tebak jawabannya oleh siswa maka pembelajaran akan menjadi kurang efisien.

Berdasarkan uraian di atas, dapat diketahui bahwa penggunaan model pembelajaran probing prompting berbantuan index card match dalam pembelajaran matematika memberikan dampak yang positif terhadap prestasi belajar matematika siswa. Sehingga dapat disimpulkan bahwa model pembelajaran probing prompting berbantuan index card match dapat digunakan dalam pembelajaran matematika sebagai upaya untuk meningkatkan prestasi belajar matematika siswa.

\section{Simpulan dan Saran}

Berdasarkan hasil penelitian dan pembahasan dapat diketahui bahwa prestasi belajar matematika siswa kelas X SMA Negeri 1 Sukasada yang mengikuti pembelajaran matematika dengan model pembelajaran probing prompting berbantuan index card match lebih baik daripada prestasi belajar matematika siswa kelas X SMA Negeri 1 Sukasada yang mengikuti pembelajaran matematika dengan model pembelajaran konvensional. Berdasarkan temuan tersebut dapat disimpulkan bahwa model pembelajaran probing prompting berbantuan index card match berpengaruh positif terhadap prestasi belajar matematika siswa.

Berdasarkan hasil penelitian yang diperoleh, peneliti mengajukan beberapa saran yaitu sebagai berikut.

a. Bagi guru mata pelajaran matematika, model pembelajaran probing prompting berbantuan index card match dapat dijadikan salah satu alternatif model pembelajaran yang dapat digunakan dalam pembelajaran di kelas dengan memperhatikan kendala yang dihadapi oleh peneliti.

b. Peneliti lain disarankan untuk mengujicobakan pengaruh model pembelajaran probing prompting berbantuan index card match terhadap aspek pembelajaran yang berbeda misalkan pada motivasi belajar matematika siswa

\section{Daftar Pustaka}

Anonim, 2011."Jurnal Pendidikan Serambi IImu (Wadah Informasi Ilmiah dan Kreativitas Intelektual Pendidikan". Dalam Abubakar dan Anwar). Strategi dan Hambatan Penerapan Quanntum Khawal dan Pencegahan Prilaku Khawal pada remanja Kota Banda Aceh (hlm. 68-90). Banda Aceh: FIKP Universitas Serambi Mekkah. 
Candiasa, I Made. 2010a. Pengujian Instrumen Penelitian Disertai Aplikasi ITEMAN dan BIGSTEP. Singaraja: Unit Penerbitan Universitas Pendidikan Ganesha.

. 2010b. Statistik Univariat dan Bivariat Disertai Aplikasi SPSS. Singaraja: Unit Penerbitan Universitas Pendidikan Ganesha.

. 2011. Statistik Multivariat Disertai Aplikasi SPSS. Singaraja: Unit Penerbitan Universitas Pendidikan Ganesha.

Dewi, Radha Tania. 2017. Pengaruh Model Pembelajaran Probing Prompting Terhadap Hasil Belajar Matematika Siswa Kelas VIII SMP Negeri L Sidoharjo Tahun Pelajaran 2017/2018[artikel ilmiah].STKIP-PGRI Lubuklinggau.

Huda, Miftahul. 2014. Model-Model Pengajaran dan Pembelajaran. Yogyakarta: Pustaka Belajar.

Lestari, Karunia E. dan M. Ridwan Y. 2015. Penelitian Pendidikan Matematika. Bandung. PT Refika Aditama

Nugraha, Dian Anita. 2013. Efektivitas Metode Pembelajaran Kooperatif Think Pair Share (TPS) yang Dilengkapi Media Kartu Berpasangan (Index Card Match) Terhadap Prestasi Belajar Siswa Pada Materi Ikatan Kimia KelasX Semester Gasal SMA N 2 Karanganyar Tahun Pelajaran 2013[skripsi]. Universitas Sebelas Maret.

Nurmawati, Eris. 2015. Pengaruh Penggunaan Metode Index Card Match Terhadap Prestasi Belajar Matematika Siswa Tunanetra Kelas V SLB-A YKAB Surakarta Tahun Ajaran 2014/2015[Skripsi]. Universitas Sebelas Maret.

PISA. 2016. "Result in Focus" [online]. Tersedia pada https://www.oecd.org/pisa/pisa-2015results-in-focus.pdf (diakses tanggal 16 Januari 2018)

Purwadi, I Made Ari. 2016. Pengaruh Model Pembelajaran Probing Prompting Terhadap Pemahaman Konsep Matematika Siswa Pada Materi Bangun Ruang Sisi Datar Kelas VIII SMPN 3 Sukasada Tahun Ajaran 2015/2016[skripsi].Universitas Pendidikan Ganesha.

Retno, Lisa Kamranti. 2016. Pengaruh Minat Belajar Pada Pelajaran Matematika Terhadap Prestasi Belajar Peserta Didik Mata Pelajaran Matematika Kelas IV MI Sultan Fatah Demak Tahun 2015/2016[skripsi]. Universitas Islam Negeri Walisongo.

Sudiarta, I G. P. 2007. Mencermati Paradigma Baru Dalam Penelitian Pendidikan Matematika. Jurnal Pendidikan dan Pengajaran UNDIKSHA. 4, 817-833.

Sudiarta, I G. P., 2010. Pengembangan model pembelajaran inovatif. Karangasem: Makalah Pelatihan MGMP.

Sukendra, I. K., Sudiarta, I. G. P., Suparta, I. N. 2014. Pengaruh Penerapan Model Pembelajaran Pemecahan Masalah Berorientasi Masalah Matematika Terbuka Terhadap Prestasi Belajar Matematika Ditinjau Dari Kemampuan Berpikir Keritis Siswa Kelas X SMA N 7 Denpasar Tahun Pelajaran 2013/2014. Universitas Pendidikan Ganesha.

Suryantini, N. K., Suparta, I N., Sudiarta, I G. P. 2016. Pembelajaran Matematika Berbasis Masalah Matematika Terbuka Dengan Keterampilan Metakognitif Untuk Meningkatkan Prestasi Belajar Matematika Siswa. Universitas Pendidikan Ganesha.

Syah, Muhibbin. 2008. Psikologi Belajar. Bandung: PT. Remaja Rosdakarya.

TIMSS (Trend in Mathematics and Science Study). 2015. [online]: Tersedia pada http://timss2015.org/timss-2015/mathematics/student-achievement/ (diakses pada tanggal 24 Januari 2018) 